Где и когда родился Гоголь: возвращение к теме

Аннотация: В статье уточнены дата и место рождения Гоголя. Принято считать, что он родился во флигеле М.Я. Трахимовского, известного украинского врача-филантропа, принимавшего роды М.И. Гоголь-Яновской. На самом деле Гоголь родился в доме генеральши Е.И. Дмитриевой. которая и стала восприемницей (крестной матерью) новорожденного. Об этом свидетельствуют друг и земляк Гоголя М.А. Максимович и С.Н. Данилевская (рожденная Быкова), внучатая племянница писателя. Кроме того, есть все основания считать научно обоснованной дату рождения Гоголя 19 марта, а не 20-го, как ошибочно указано в церковной метрической книге. На этот счет сохранились неопровержимые свидетельства родных Гоголя (матери, сестер), близких друзей, его биографов. Если документ вступает в противоречие с другими фактами и не подтверждается иными свидетельствами, он не может считаться достоверным.

Ключевые слова: Гоголь, день и место рождения, церковные метрические книги, свидетельства современников

V.A. Voropaev (Moscow, Russia)

\title{
Where and When Gogol was Born: Returning to the Question
}

Abstract: The article clarifies the date and place of birth of Nikolay Gogol. It is believed that he was born in the fligel of M.Ya. Trakhimovsky, the famous Ukrainian philanthropist, who helped M.I. Gogol-Yanovskaya during childbirth. In fact, Gogol was born in the house of a General's wife E.I. Dmitrieva, who became the godmother of the newborn. This is evidenced by a friend and countryman of Nikolay Gogol M.A. Maksimovich and S.N. Danilevskaya (nee Bykova), the great-niece of the writer. Besides, there is every reason to consider the date of Gogol's birth on March 19 , rather than the $20^{\text {th }}$, as erroneously stated in the church metric book. The irrefutable evidences of Gogol's relatives (mothers, sisters), close friends, and his biographers remained on this account. If the document conflicts with other facts and is not supported by other evidences, it cannot be considered reliable.

Key words: Nikolay Gogol, day and place of birth, church metric books, evidences of contemporaries 
Вопрос, вынесенный в заглавие, может кому-то показаться странным. И тем не менее он существует. Если мы обратимся к энциклопедическим изданиям (как советским, так и современным российским) и работам маститых гоголеведов, например Игоря Золотусского ${ }^{1}$ или Юрия Манна² (называю самые известные имена), то прочтем, что Гоголь родился в 1809 г. 20 марта или 1 апреля по новому стилю. Однако если Гоголь родился 20 марта, то отмечать день его рождения мы должны 2 апреля по новому европейскому календарю (В нашем столетии при пересчете со старого стиля на новый прибавляется 13 дней.) Кроме того, и это главное, - Гоголь родился 19 марта, а не 20-го. На этот счет есть неопровержимые доказательства.

По свидетельству Марии Ивановны Гоголь-Яновской, матери писателя, он родился «в 9 году 19 марта»³. Двоюродная сестра Гоголя, Мария Николаевна Синельникова (рожденная Ходаревская), писала Степану Петровичу Шевыреву (другу и душеприказчику Гоголя) 15 апреля 1852 г.: «День его рождения мне очень памятен - 19 марта, в один день с его меньшой сестрой Ольгой...» ${ }^{4}$. Ольга Васильевна Гоголь (в замужестве Головня) родилась, как известно, 19 марта 1825 г. и не раз говорила, что появилась на свет в один день с братом. «Он был на шестнадцать лет старше меня, - вспоминала она, - он родился в девятом, а я - в двадцать пятом году, и заметьте, в один и тот же день, 19 марта, родились мы: он - первый сын и я - последняя дочь в нашей семье» ${ }^{5}$.

В 1852 г., вскоре после кончины Гоголя, Отделение русского языка и словесности Российской Академии наук приняло решение издать его биографию. Написать ее было поручено Шевыреву. Летом 1852 г. он отправился на родину писателя для сбора материала. В своем путевом дневнике Шевырев со слов родственников Гоголя сделал запись: «Родился 1809 года, 19-го марта, в 9 часов вечера. Слово Трофимовского ${ }^{6}$, когда он смотрел на новорожденного: будет славный сын» ${ }^{7}$

Принято считать, что Гоголь родился во флигеле доктора М.Я. Трофимовского, принимавшего роды Марии Ивановны. Между тем, по авторитетному свидетельству земляка и одного из ближайших друзей Гоголя, Михаила Александровича Максимовича, квартира Марии Ивановны Гоголь-Яновской в Сорочинцах «была в домике генеральши Дмитриевой ${ }^{8}$, в котором и родился 19-го марта Николай

\footnotetext{
${ }^{1}$ См.: Золотусский И.П. Гоголь. 7-е изд. М., 2009. (Жизнь замечательных людей).

${ }^{2}$ См.: Манн Ю.В. Гоголь. Книга первая. Начало: 1809-1835 годы. М., 2012.

${ }^{3}$ Гоголь в воспоминаниях, дневниках, переписке современников. Полный систематический свод документальных свидетельств. Научно-критическое издание: В 3 т. Т. 1. М., 2011. С. 265.

${ }^{4}$ Там же. С. 263-264.

5 Там же. С. 249.

${ }^{6}$ Трофимовский (Трахимовский, Трохимовский) Михаил Яковлевич (1730-1815), известный украинский врач-филантроп.

${ }^{7}$ Гоголь в воспоминаниях, дневниках, переписке современников. Т. 1. С. 11.

8 Дмитриева Екатерина Ивановна, бездетная вдова генерал-майора А. Дмитриева, героя русско-турецкой войны 1768-1774 гг., кавалера ордена св. Георгия 4-й степени. В 1800-1830 гг. проживала в Сорочинцах, где имела дом и крепостных; у нее воспитывалась сестра Гоголя Ольга Васильевна Гоголь-Головня, она учила девочку грамоте и рукоделию (см.: Розсоха Л. Миргородщина козацька і гоголівська. Київ, 2009. С. 169).
} 
Васильевич Гоголь. Восприемниками его были: молодой Трофимовский Михайло Михайлович ${ }^{1}$, и Дмитриева»².

Софья Николаевна Данилевская (рожденная Быкова), внучатая племянница Гоголя, со слов его сестер рассказывает: «Я хорошо помню младшую сестру писателя - Ольгу Васильевну. Мне было 20 лет, когда она умерла. Ее часто навещали художники, писатели, журналисты. Они всегда останавливались в нашей Васильевке, в доме моего отца, Николая Владимировича Быкова. Он был любимым внуком матери писателя Марии Ивановны Гоголь-Яновской и воспитанником Анны Васильевны, его сестры. Они свидетельствовали приезжим журналистам со слов матери, что Николай Васильевич родился в доме генеральши Протасовой (ошибка памяти, имеется в виду Е.И. Дмитриева. - B.B.) Но газетчики зачем-то выдумали небылицу, будто Гоголь родился во флигеле доктора Трахимовского. И что этот домик был крыт соломой, а в комнате имелся только глиняный пол! В действительности доктор арендовал землю у генеральши и поставил флигель для крепостных крестьянок. Надо отметить, что моя бабушка Елизавета Васильевна Гоголь, как и ее сестры, родилась в доме генерал-майора Андрея Андреевича Трощинского, двоюродного брата матери писателя. При крещении ее держал на руках сам бывший министр юстиции и сенатор Дмитрий Прокофьевич Трощинский, а крестной матерью была Ольга Дмитриевна, внучка последнего короля Польши Станислава Понятовского. Журналисты не понимают, что мать Гоголя принадлежала к высшему сословию, поэтому не могла рожать во флигеле вместе с крепостными крестьянками» ${ }^{3}$.

Именно 19 марта отмечали день рождения Гоголя его друзья. Тот же Михаил Максимович писал Сергею Тимофеевичу Аксакову 19 марта 1857 г.: «Сегодня день рождения нашего незабвенного Гоголя, и мне живо вспомянулось, как за семь лет мы с ним обедали у Вас в этот день взятия Парижа! ${ }^{4}$ Боже мой, как хорошо мне прожилось в тот март месяц и как часто я тогда проводил у Вас время с Гоголем...» $\nu^{5} 19$ марта 1849 г. Гоголь праздновал свое сорокалетие у С.Т. Аксакова. В следующем 1850 г. он обедал в этот день у Аксаковых вместе с М.А. Максимовичем и О.М. Бодянским. Присутствовали также А.С. Хомяков и С.М. Соловьев. Пили за здоровье Гоголя и пели украинские народные песни.

19 марта поздравляли Гоголя с днем рождения родные и близкие ему по духу люди. «Письмо ваше (от 19 марта) с поздравлением пришло ко мне в тот день, когда я удостоился приобщиться Св<ятым> Тайнам», - сообщал Гоголь матери и

\footnotetext{
${ }^{1}$ Трахимовский (Трохимовский, Трофимовский) Михаил Михайлович, сын М.Я. Трахимовского. После двадцати лет военной службы вышел в отставку и поселился в Сорочинцах; военный советник (по Табели о рангах соответствовал чину полковника); женат на внебрачной дочери графа П.Г. Разумовского. Известен портрет М.М. Трахимовского работы В.Л. Боровиковского (1802), где он изображен в армейском офицерском мундире с орденом Св. Анны 2-й степени (См.: «...Красоту ее Боровиковский спас»: Каталог выставки в Государственной Третьяковской галерее. М, 2008).

2 Гоголь в воспоминаниях, дневниках, переписке современников. Т. 1. С. 639-640.

3 Там же. С. 967.

4 День рождения Гоголя совпал с днем взятия русскими войсками Парижа в 1814 г., и впоследствии он праздновал оба эти события вместе.

${ }_{5}^{5}$ Гоголь в воспоминаниях, дневниках, переписке современников. Т. 1. С. 642.
} 
сестрам 3 апреля 1849 г. ${ }^{1}$ Надежда Николаевна Шереметева, тетка поэта Федора Тютчева, писала Гоголю 12 февраля 1843 г. из подмосковного Покровского: «Я к вам хотела писать и не получа письма вашего, чтобы к 19 марта достигло до вас мое поздравление. Поздравляю вас, мой милый друг, с рождением; важен для христианина этот день, получаем право наследовать вечное блаженство, как и получим, если пройдем здешнее странствие, как должно христианину...»²

Биографы Гоголя, в первую очередь П.А. Кулиш и В.И. Шенрок, считали датой рождения писателя 19 марта. Сомнения в этом возникли после публикации выписки из метрической книги Спасо-Преображенской церкви в Сорочинцах, где крестили Гоголя. Здесь под № 25 сделана следующая запись: «Марта 20 числа у помещика Василия Яновского родился сын Николай и окрещен 22. Молитствовал и крестил священнонаместник Иоанн Беловольский». В графе о восприемнике указан «господин полковник Михаил Трахимовский».

Выписку из метрической книги впервые опубликовал А.И. Ксензенко ${ }^{3}$. Позднее (в 1908 г.) появилась ее фотокопия. На ошибочность указанной здесь даты рождения Гоголя настаивали многие исследователи 4 . Не секрет, что метрические записи в церковных книгах, давая верную дату крещения, часто ошибаются в дате рождения. Пример подобной ошибки находим и в отношении А.С. Пушкина. Известно, что поэт родился 26 мая. Между тем в церковной метрической книге рождение Пушкина датировано 27 мая. Если документ вступает в противоречие с другими фактами и не подтверждается иными свидетельствами, он не может считаться достоверным.

Таким образом, есть все основания считать научно обоснованной дату рождения Гоголя именно 19 марта, а не 20-го (как ошибочно указано в метрической книге) и соответственно отмечать день рождения писателя 1-го апреля по новому стилю.

\section{ЛИТ Е РАТ У РА}

Гоголь Н.В. Полн. собр. соч. и писем: В 17 т. / Сост., подгот. текстов и коммент. И.А. Виноградова, В.А. Воропаева. М.; Киев: Изд-во Московской Патриархии, 2009-2010.

Гоголь в воспоминаниях, дневниках, переписке современников. Полный систематический свод документальных свидетельств. Научно-критическое издание: В 3 т. / Издание подгот. И.А. Виноградов. М.: ИМЛИ РАН, 2011-2013.

Золотусский И.П. Гоголь. 7-е изд. М., 2009. 496 с. (Серия «Жизнь замечательных людей»).

Лернер Н. О дне рожденья Гоголя // Русская старина. 1909. № 5. С. 319-320.

Манн Ю.В. Гоголь. Книга первая. Начало: 1809-1835 годы. [2-е изд., перераб. и доп.] М.: РГГУ [Российский гос. гуманитарный ун-т], 2012. 504 с.

Розсоха Л. Миргородщина козацька і гоголівська / Миргородська міська рада, Миргородський краєзнавчий музей. Київ: ТОВ ВБ «Аванпост-прим». 2009. 396 с. (Серія «Миргородські джерела») (До 200-річчя від дня народження М.В. Гоголя). На обложке: Миргород, 2008.

\footnotetext{
${ }^{1}$ Гоголь Н.В. Полн. собр. соч. и писем: В 17 т. Т. 15. С. 174.

2 Там же. Т. 12. С. 195.

${ }^{3}$ Русская Старина. 1888. № 10. С. 392.

${ }^{4}$ См. например: Лернер Н. О дне рожденья Гоголя // Русская Старина. 1909. № 5.
} 


\section{RE F E R E N C E S}

The Complete Works and Letters: In 17 vols. / Comp., prepar. of the texts, comment. by I.A. Vinogradov, V.A. Voropaev. Moscow; Kiev. Moscow Patriarchate Publishing House. 2009-2010.

Gogol in Memoirs, Diaries, Correspondence of Contemporaries. The Complete Systematic Collection of Documentary Evidences. Scientific-Critical Edition: In 3 vols. / Edition is prepared by I.A. Vinogradov. Moscow. Gorky Institute of World Literature, RAS. 2011-2013.

Zolotussky I.P. (2009) Gogol. $7^{\text {th }}$ ed. Moscow. 496 p. (Series: “The Life of Remarkable People”).

Lerner N. About the Birthday of Gogol. Russkaya Starina. 1909. No 5, pp. 319-320.

Mann Yu.V. (2012) Gogol. Book One. The Beginning: 1809-1835 years. [2 $2^{\text {nd }}$ ed., revised and enlarged] Moscow. Russian State University for the Humanities Press. 504 p.

Rozsokha L. Mirgorod of Cossacks and Gogol / Mirgorodsky City Council, Mirgorod Local History Museum. Kiev. Avanpost-Prim Publ. 2009. 396 p. (Series "Mirgorod sources") (To the $200^{\text {th }}$ Anniversary of N.V. Gogol's Birth). On the cover: Mirgorod, 2008.

Сведения об авторе:

Владимир Алексеевич Воропаев,

доктор филол. наук

профессор

филологический факультет

МГУ имени М.В. Ломоносова
Vladimir A. Voropaev,

Doctor of Philology

Professor

Philological Faculty

Lomonosov Moscow State University

voropaevvl@bk.ru 